\title{
Motivation to transfer learning to multiple contexts
}

\author{
Laurent Testers \\ NHTV Breda University of Applied Sciences \\ PO Box 3917, 4800 DK Breda \\ The Netherlands \\ testers.|@nhtv.nl \\ Andreas Gegenfurtner \\ Maastricht University \\ Maastricht \\ The Netherlands \\ Saskia Brand-Gruwel \\ Open University of the Netherlands \\ The Netherlands
}

\begin{abstract}
To stay up-to-date in contemporary information intensive societies it is important to be able to effectively and efficiently find, evaluate, process and present required information. In educational contexts training in these so-called information literacy competences is mainly the domain of institutional libraries. Essential to education is the long-term transfer of learning, that is the application of newly acquired competencies also outside the training environment. Research learns that this often takes place sparsely, leading to what is called a Transfer Paradox. The aim of this study is to develop a practical instrument for instructional designers to measure the influence of a set of key variables on the learner's motivation to transfer learning to the wider educational and the work context. Two hundred and thirty-four students of the Open University of the Netherlands doing an information literacy course filled out a questionnaire before entering the course. Data was analyzed using factor analyses and hierarchical multiple regression analysis. Results show that the opportunity to apply new learning and sanctions from supervisors are two important factors that influence the learner's motivation to transfer learning in both the study and the work context already before the course has started.
\end{abstract}

Keywords: Transfer of learning, Transfer of training, Motivation to transfer, Information literacy 


\section{Introduction}

In contemporary so-called information or knowledge societies it becomes increasingly important to stay up-to-date with the latest developments in various walks of life. Lifelong learning is high on the agenda of renown organizations like UNESCO, the European Commission, and the World Bank and knowing how to learn is becoming more important than ready but fast dating knowledge. In a time that is characterized by what is called information obesities it is important to know how to find your way in the ever growing amount of information resources and formats. This requires a certain level of context-specific information literacy. This is the competence to find, critically analyze, process and present required information in an effective and efficient way. In educational contexts this is preeminently the field of activity of institutional libraries.

It is widely accepted that transfer of learning, defined as the application of learning also outside the training context, is essential to all forms of education. However, ample research in disciplines like human resource development (HRD), psychology, and education learn that transfer is not self-evident. How fluently and unconscious it might occur in daily life, it often seems to take place sparsely or not at all in educational settings (Ford, Yelon, \& Billington, 2011; Haskell, 2001; Yamnill \& McLean, 2001), resulting in a so-called Transfer Paradox (Merriënboer \& Kirschner, 2007) or Transfer Problem (Baldwin \& Ford, 1988; Haskell, 2001). The aim of this study is to offer means to enhance transfer of learning and contribute to solving this transfer paradox by complementing previous research in various ways.

Past research on transfer has often taken place from the perspective of the researcher or instructional designer. In this study transfer will be considered a more or less conscious decision by the learner on e.g. how, where, and when to transfer newly acquired competences (Baldwin, Ford, \& Blume, 2009; E. W. Cheng \& Hampson, 2008). It therefore will be studied from the perspective of the learner by means of a self-report questionnaire.

Previous studies have considered transfer often within one specific context, predominantly education or work. This is not only reflected in the various definitions of transfer but also in the fact that in educational settings transfer is often measured in a one-shot test directly after a course or training. This focus on one single context however doesn't always reflect reality, especially when it concerns education in more generic competences like information literacy that can be applied in various contexts. And in specific educational settings like universities of applied sciences or open universities learning is strongly directed towards application in the student's current or prospective work setting.

Furthermore research on transfer has often been focused on course or training content, design and delivery. Based on a comprehensive literature review Baldwin and Ford (1988) defined three domains of variables that might influence the transfer process: the individual learner, the intervention (e.g. a course or training), and the application environment. The latter is often referred to as the organizational climate and is conceptualized as observable or perceived situations in organizations that inhibit or facilitate the use of learned skills (Rouiller \& Goldstein, 1993). Ample studies have underlined the importance of organizational climate factors on the transfer process and more specifically on motivation to transfer. For this study we have focused on variables related to two application environments: the student's educational context (Open University) and their work environment. 
The variables used in this study have been derived from the literature (Blume, Ford, Baldwin, \& Huang, 2010; Burke \& Hutchins, 2007; E. W. Cheng \& Hampson, 2008; Gegenfurtner, Veermans, Festner, \& Gruber, 2009) and from the Learning Transfer System Inventory by Holton and colleagues (2000). The latter is an extensively validated instrument to measure the influence of sixteen constructs in five domains on the transfer process. Figure 1. gives an overview of the variables that are used in this study.

\section{Study}

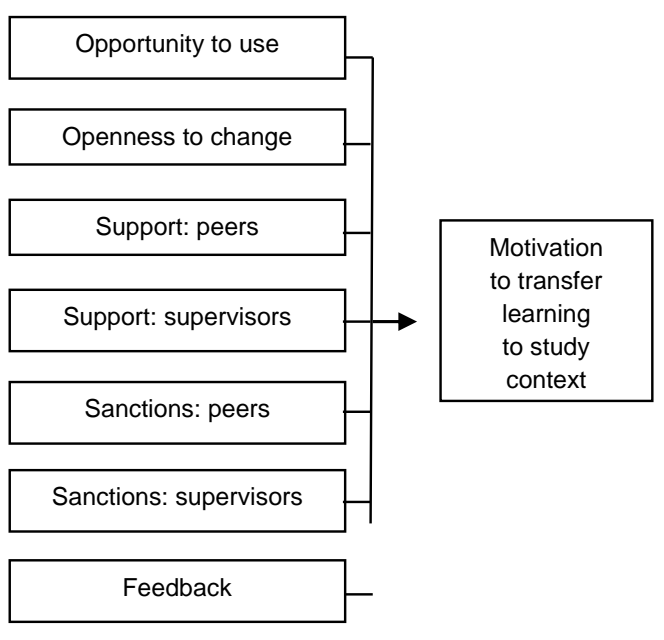

Work

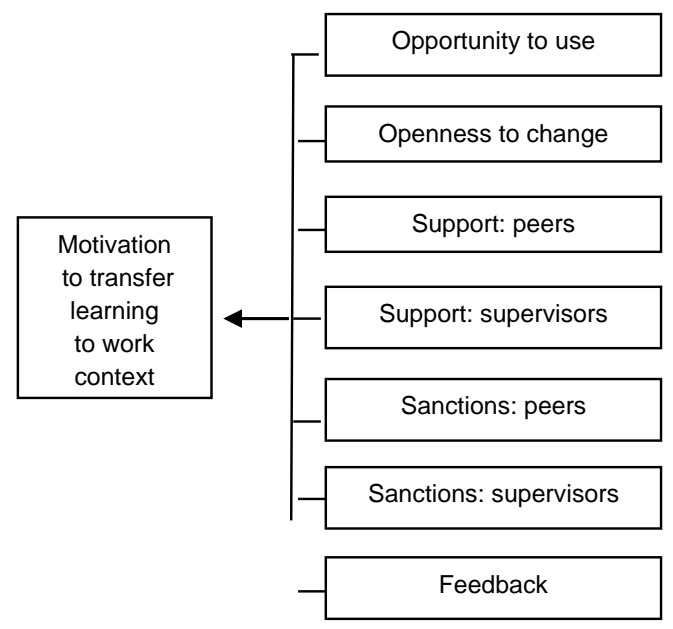

Figure 1. Organizational climate factors influencing motivation to transfer learning to the learner's study and work setting

\section{Motivation to transfer}

The variable motivation in a transfer of learning context is defined as "a learner's desire to apply skills, knowledge and/or attitudes mastered in an intervention" (Noe, 1986). It is considered the motor for action and crucial to the transfer process ( $(\mathrm{E} . \mathrm{W}$. Cheng \& Ho, 2001; Colquitt, LePine, \& Noe, 2000; Gegenfurtner, 2011; Noe, 1986). Without motivation (in Latin: movare $=$ to move) nothing moves. One can create optimal conditions for successful transfer but when a learner is not motivated nothing will happen. On the other hand, motivated students will find ways to transfer new learning when relevant information and facilities are lacking. In this study motivation will be differentiated into two variables: motivation to transfer to the study environment and motivation to transfer to work and will be considered the key, and therefore dependent, variable.

\section{Opportunity to use}

Providing learners with the time, opportunities and facilities to practice their newly gained competences is considered in many studies to be a strong or even critical predictor of both transfer of learning (Baldwin \& Ford, 1988; De Rijdt, Stes, van der Vleuten, \& Dochy, 2013) and of motivation to transfer (Gegenfurtner et al., 2009; Seyler, Holton III, Bates, Burnett, \& Carvalho, 1998). This situational variable or cue is closely related to supervisory (Ford, Quinones, Sego, \& Sorra, 1992) and peer (Russ-Eft, 2002) support and to the construct openness to change within the organization's work climate. From her extended literature 
review Burke (2007) concluded that opportunity to use was the most influential form of support to learners and its absence was rated the biggest obstacle to transfer.

\section{Openness to change}

Holton (2000) conceptualizes resistance to change, as opposite to openness to change, as "the extent to which prevailing group norms are perceived by individuals to resist or discourage the use of skills and knowledge acquired in training". In Ajzen's Theory of Planned Behavior (1991) it is referred to as 'subjective norms' that influence the intention to apply a specific behavior and ultimately behavior itself. According to a study by Ruona (2002) openness to change is also a predictor for motivation to transfer. Perceived or subjective norms in the application environment also correlate to other constructs used in this research. Supervisor and peer support and sanctions may be based on a personal interpretation and application of the organization's standards and values. A rigid organization, supervisor or peer might also inhibit the opportunity to use newly acquired competences by withholding suitable tasks and facilities to practice from the learner.

\section{Support \& Sanctions}

Support and sanctions are two sides of the same coin. Many studies acknowledge the importance of support, or its counterpart sanctions, to the transfer process (Baldwin \& Ford, 1988; Blume et al., 2010; Burke \& Hutchins, 2007; Nijman, 2004) and to motivation to transfer (Facteau, Dobbins, Russell, Ladd, \& Kudisch, 1995; Gegenfurtner et al., 2009). This is not surprising as learners who encounter negative reactions when applying newly acquired competences might avoid doing so. The manifestation of support can be manifold, varying from providing encouragement and coaching, discussing new learning, setting proximal and distal goals, to actual involvement in the course or training itself. This can take place before, during and after an intervention. In this study peers and supervisors in the study context were students and lecturers, in the work context they were supervisors.

\section{Feedback}

The Oxford Dictionary defines feedback as the reaction to a person's performance of a task, in this case the application of new learning, which is used as a basis for improvement. It is an established predictor of both learning and transfer and is often bracketed together with performance coaching. It's also one of the important factors in Instructional Systems Design, in learning theories like Bandura's Social Learning Theory (1977) and McClelland's Achievement Need Theory (1961). And it plays an important role in motivation theories like Edwin Locke's Goal Setting Theory (1968) where motivation and performance are expected to be high if individuals are set challenging but accepted goals and when they receive feedback on their performance. Although one can make a distinction between positive and negative feedback at various moments and related to various aspects of the task performance, in this study feedback is considered a one-dimensional construct.

To support the design of educational interventions that enhance transfer of learning to multiple settings this study intents to contribute to the design of a practical instrument to measure the most relevant variables that influence the transfer process. Focussing on variables from the application domain, that is the organizational climate, this results in the following research question: which variables from the application domain influence student's transfer of learning from an information literacy course at the Open University in the 
Netherlands to both their study and work environment. The following research hypotheses have been tested:

H1 Opportunity to use, openness to change, peer support, supervisor support, peer sanctions, supervisor sanctions and feedback will each correlate with motivation to transfer new learning to the study and to the work context

H2 Opportunity to use will be responsible for a significant variance in the motivation to transfer new learning to the study and the work context

H3 Openness to change will be responsible for a significant variance in the motivation to transfer new learning to the study and the work context

$\mathrm{H} 4 \quad$ Peer support will be responsible for a significant variance in the motivation to transfer new learning to the study and the work context

H5 Supervisor support will be responsible for a significant variance in the motivation to transfer new learning to the study and the work context

H6 Supervisor sanctions will be responsible for a significant variance in the motivation to transfer new learning to the study and the work context

$\mathrm{H} 7 \quad$ Feedback will be responsible for a significant variance in the motivation to transfer new learning to the study and the work context

\section{Method}

\section{Participants}

The participants in this study were 234 adult students of the premaster Learning Sciences at the Open University of the Netherlands. Most students were in their first year of study and have been following a mandatory course in Information Literacy. Beside their study at the Open University students mainly work in primary and secondary education, higher education, and training. Of the participants $81 \%$ were female and $19 \%$ were male. Of the students $40 \%$ was younger than 25; $25 \%$ was between 25 and 35 years old; $18 \%$ was between 35 and 45 years old; $14 \%$ was between 45 and 55 years old, and $2 \%$ was between 55 and 65 years old. One person was older than 65 and one student didn't mention his or her age.

\section{Context}

The web-based course Information Literacy for Social Scientists (4,3 ECTS, equal to 120 hours of study) is for almost all students mandatory in order to enter the master Learning Sciences at the Open University. The Association of College and Research Libraries (ACRL) defines information Literacy for higher education as "the set of integrated abilities encompassing the reflective discovery of information, the understanding of how information is produced and valued, and the use of information in creating new knowledge and participating ethically in communities of learning" (2015). During the course students learn how to effectively and efficiently define research questions, search words and concepts, find and use the appropriate information resources, critically evaluate and in depth process the information, and present it in a proper and ethical way. Information literacy is considered a 
generic competence as the acquired knowledge, skills and attitude can be applied not only in an educational or academic setting but also in other contexts like work and private life.

During the course students worked on five authentic tasks with varying support, gathering information in a structured way. They reported on the steps they took during this process by means of a process worksheet (Brand-Gruwel, Wopereis, \& Walraven, 2009). At the end of the process students were provided with feedback on their performance by their lecturers. One of the tasks is for example: Imagine you are a teacher in primary education and you want to know more about how to stimulate and support collaborative learning amongst your students. Study four information sources using the checklist 'Critical Reading' and write a short essay (600 words) in which you answer your research questions and critically reflect on them.

\section{Questionnaire}

The instrument used in this study was a self-report Dutch questionnaire, consisting of 18 constructs, 79 questions and 148 work and study related items. A 7-point Likert scale was used ranging from 1 (strongly disagree) to 7 (strongly agree).

Exploratory factor analyses (extraction method: principle axis factoring) were performed to identify scales as this method is preferred to principle component analysis (Costello \& Osborne, 2005). For rotation method oblique rotation (direct oblimin) was used as correlations between the factors were expected. This resulted in two scales for measuring motivation (motivation to transfer to study, motivation to transfer to work) and study and work related scales for each of the independent variables. Table 1 shows the various scales, the number of items, an example of an item from the questionnaire, and the reliability coefficient (Cronbach's Alpha).

\section{$\begin{array}{llll}\text { Scales } & \text { Items } & \text { Example } & \alpha\end{array}$}

\begin{tabular}{|c|c|c|c|}
\hline \multicolumn{4}{|l|}{ Motivation to transfer } \\
\hline Motivation to transfer to study & 4 & $\begin{array}{l}\text { I will apply the newly gained } \\
\text { competences because I value the } \\
\text { benefits of the course for my study }\end{array}$ & .71 \\
\hline Motivation to transfer to work & 4 & $\begin{array}{l}\text { I will apply the newly gained } \\
\text { competences because I value the } \\
\text { benefits of the course for my work }\end{array}$ & .90 \\
\hline \multicolumn{4}{|l|}{ Independent variables } \\
\hline Opportunity to use & $\begin{array}{l}3(\mathrm{~s}) \\
3(\mathrm{w})\end{array}$ & $\begin{array}{l}\text { I expect to get sufficient opportunities to } \\
\text { practice the newly gained competences } \\
\text { in my study } \\
\text { in my work }\end{array}$ & $\begin{array}{l}.89(\mathrm{~s}) \\
.97 \\
(\mathrm{w})\end{array}$ \\
\hline Openness to change & $\begin{array}{l}3(\mathrm{~s}) \\
3(\mathrm{w})\end{array}$ & $\begin{array}{l}\text { There is an open attitude towards } \\
\text { change when it will improve } \\
\text { performance of my group/team }\end{array}$ & $\begin{array}{l}.80(s) \\
.97 \\
(w)\end{array}$ \\
\hline
\end{tabular}




\begin{tabular}{|c|c|c|c|}
\hline Scales & Items & Example & $\alpha$ \\
\hline & & $\begin{array}{l}\text { at the OU } \\
\text { in my work environment }\end{array}$ & \\
\hline Support: peers & $\begin{array}{l}3(s) \\
3(w)\end{array}$ & $\begin{array}{l}\text { I expect that applying the newly gained } \\
\text { competences will be appreciated by my } \\
\text { fellow students } \\
\text { colleagues }\end{array}$ & $\begin{array}{l}.95(\mathrm{~s}) \\
.98 \\
(\mathrm{w})\end{array}$ \\
\hline Support: supervisors & $\begin{array}{l}3(\mathrm{~s}) \\
3(\mathrm{w})\end{array}$ & $\begin{array}{l}\text { I expect that applying the newly gained } \\
\text { competences will be appreciated by my } \\
\text { lecturers } \\
\text { supervisors }\end{array}$ & $\begin{array}{l}.96(\mathrm{~s}) \\
.99 \\
(\mathrm{w})\end{array}$ \\
\hline Sanctions: supervisors & $\begin{array}{l}3(s) \\
3(w)\end{array}$ & $\begin{array}{l}\text { This course will not be considered } \\
\text { helpful for my performance by my } \\
\text { lecturers } \\
\text { supervisors }\end{array}$ & $\begin{array}{l}.78(s) \\
.89 \\
(w)\end{array}$ \\
\hline Feedback & $\begin{array}{l}3(s) \\
3(w)\end{array}$ & $\begin{array}{l}\text { After the course I expect to receive } \\
\text { feedback on how well I am applying my } \\
\text { newly gained competences from my } \\
\text { lecturers } \\
\text { supervisors }\end{array}$ & $\begin{array}{l}.85(\mathrm{~s}) \\
.91 \\
(\mathrm{w})\end{array}$ \\
\hline
\end{tabular}

Table 1. Overview of pre-intervention scales for the study (s) and work (w) context

\section{Data collection}

The online survey used in this study was mandatory. It was embedded in the electronic learning environment of the master Learning Sciences and integrated in the course curriculum as Task 0 . Students were requested to fill in the questionnaire before they started the course. They received instructions on forehand on how to complete the instrument and anonymity was guaranteed.

\section{Data analysis}

Bivariate correlation analysis was used to test hypothesis one, investigating the relationships between the two dependent motivation variables and each of the independent variables in a study and work context.

Hypotheses two to seven were tested by using hierarchical multiple regression. The factors were added to the analysis separately for study and work in the following order: (1) opportunity to use; (2) openness to change; (3) support peers; (4) support supervisors; (5) sanctions supervisors; and (6) feedback. 


\section{Results}

\section{Hypothesis 1}

To test hypothesis 1 bivariate correlation analysis was conducted to investigate the relationships between the six independent variables and the dependent variable motivation to transfer. In relation to the study context all correlations were statistically significant while the strongest correlations existed between motivation to transfer to study and opportunity to use $(r=0.43)$, supervisor (lecturer) sanctions $(r=0.39)$, and supervisor (lecturer) support $\quad(r$ $=0.36)$. Openness to change gives the lowest score $(r=.21)$. Table 2 offers an overview of all correlations related to motivation to transfer to study.

\begin{tabular}{|c|c|c|c|c|c|c|c|}
\hline Variables related to study & 1 & 2 & 3 & 4 & 5 & 6 & 7 \\
\hline 1. Motivation to transfer to study & $(.71)$ & & & & & & \\
\hline 2. Opportunity to use &, $43^{* *}$ & $(.89)$ & & & & & \\
\hline 3. Openness to change & $21^{* \star}$ & $39^{* *}$ & $(.80)$ & & & & \\
\hline 4 Support peers (stud.) &, $31^{* *}$ & $40^{* *}$ & $30^{* *}$ & (.95) & & & \\
\hline 5. Support supervisors (lec.) &, $36^{* *}$ &, $47^{* *}$ & $31^{* *}$ &, $76^{* *}$ & $(.96)$ & & \\
\hline 6. Sanctions supervisors (lec.) &, $39^{* *}$ & $21^{\star *}$ & $28^{* *}$ &, $39^{* *}$ &, $38^{* *}$ & $(.78)$ & \\
\hline 7. Feedback & ,29** &, $59^{* *}$ & $37^{* *}$ &, $37^{* *}$ &, $30^{\star \star}$ & $18^{* *}$ & $(.85)$ \\
\hline
\end{tabular}

${ }^{* *} p<0.01$ level (1-tailed), $\mathrm{N}=234$

Table 2. Pearson correlation coefficients for bivariate relationships between motivation to transfer to study and six independent study-related variables

Bivariate correlation analysis related to the work context showed that correlations between motivation to transfer to work and the six independent variables were statistically significant. Although the scores didn't diverge much, the strongest correlations existed between motivation to transfer to work and opportunity to use $(r=0.60)$ and openness to change $(r=$ $0.59)$, followed by supervisor support $(r=0.58)$, peer support $(r=0.58)$ and feedback $(r=$ 0.57 ). Table 3 gives an overview of all correlations related tot motivation to transfer to work.
Variables related to work
$1 \quad 2 \quad 3$
4
56
7

1. Motivation to transfer to work $\quad(.90)$

2. Opportunity to use $\quad, 60^{* \star} \quad(.97)$

3. Openness to change $\quad, 59^{* *} \quad, 82^{* *} \quad(.97)$ 


\begin{tabular}{|c|c|c|c|c|c|c|c|}
\hline Variables related to work & 1 & 2 & 3 & 4 & 5 & 6 & 7 \\
\hline 4 Support peers (col.) &, $58^{* *}$ & ,74 &, $71^{* *}$ & $(.98)$ & & & \\
\hline 5. Support supervisors (sup.) &, $58^{* \star}$ &, $65^{\star *}$ &, $63^{* *}$ &, $80^{* \star}$ & (.99) & & \\
\hline 6. Sanctions supervisors (sup.) &, $54^{\star \star}$ &, $55^{\star \star}$ &, $56^{\star *}$ &, $65^{\star \star}$ &, $73^{\star \star}$ & $(.89)$ & \\
\hline 7. Feedback &, $57^{\star *}$ &, $70^{\star *}$ &, $74^{\star *}$ &, $72^{\star \star}$ &, $80^{\star *}$ &, $70^{\star \star}$ & $(.91)$ \\
\hline${ }^{* *} \mathrm{p}<0.01$ level (1-tailed), $\mathrm{N}=23$ & & & & & & & \\
\hline
\end{tabular}

\section{Hypotheses 2-7}

Hierarchical multiple regression analysis was used to test hypotheses two till seven and see how each independent variable related to motivation to transfer. The scores for Tolerance and VIF didn't reveal any multicollinearity, making the data suitable for regression analysis. Table 4 and 5 show the results for motivation to transfer to study and motivation to transfer to work respectively.

\begin{tabular}{|c|c|c|c|c|c|c|}
\hline Predictor & B & SEb & B & $\mathbf{R}^{2}$ & Adj. $R^{2}$ & $\Delta R^{2}$ \\
\hline Model 1 & & & & .184 & .180 & .184 \\
\hline Opportunity to use & .409 & .057 & $.43^{\star * *}$ & & & \\
\hline Model 2 & & & & .186 & .179 & .002 \\
\hline Opportunity to use & .389 & .061 & $.41^{\star \star \star}$ & & & \\
\hline Openness to change & .052 & .063 & .05 & & & \\
\hline Model 3 & & & & .209 & .199 & .023 \\
\hline Opportunity to use & .337 & .064 & $.35^{\star * \star}$ & & & \\
\hline Openness to change & .024 & .063 & .02 & & & \\
\hline Support: peers & .148 & .057 & $.17^{\star \star}$ & & & \\
\hline Model 4 & & & & .219 & .206 & .010 \\
\hline Opportunity to use & .308 & .066 & $.32^{\star \star \star}$ & & & \\
\hline Openness to change & .018 & .063 & .02 & & & \\
\hline Support: peers & .049 & .080 & .06 & & & \\
\hline Support: supervisors & .143 & .082 & .17 & & & \\
\hline Model 5 & & .063 & & .289 & .274 & .070 \\
\hline Opportunity to use & .316 & .061 & $.33^{\star \star \star}$ & & & \\
\hline Openness to change & -.032 & .077 & -.03 & & & \\
\hline Support peers & -.002 & .079 & .002 & & & \\
\hline
\end{tabular}




\begin{tabular}{|c|c|c|c|c|c|c|}
\hline Predictor & B & SEb & $\boldsymbol{B}$ & $\mathbf{R}^{2}$ & Adj. $R^{2}$ & $\Delta \mathbf{R}^{2}$ \\
\hline Support supervisors & .094 & .060 & $.11^{\star \star \star}$ & & & \\
\hline Sanctions Supervisors & .285 & & .29 & & & \\
\hline Model 6 & & & & .290 & .272 & .001 \\
\hline Opportunity to use & .296 & .073 & $.31^{* * *}$ & & & \\
\hline Openness to change & -.038 & .062 & -.049 & & & \\
\hline Support peers & -.011 & .079 & -.01 & & & \\
\hline Support supervisors & .100 & .080 & .12 & & & \\
\hline Sanctions supervisor & .285 & .060 & $.29^{* * *}$ & & & \\
\hline Feedback & .035 & .066 & .04 & & & \\
\hline \multicolumn{7}{|c|}{$\begin{array}{l}\text { Table 4. Results of the hierarchical multiple regression predicting motivation to transfer from Opportunity to Use, Openness t } \\
\text { Change, Support-peers, Support-supervisors, Sanctions-supervisors, and Feedback for the study context. }\end{array}$} \\
\hline Predictor & b & SEb & B & $\mathbf{R}^{2}$ & Adj. $R^{2}$ & $\Delta \mathbf{R}^{2}$ \\
\hline Model 1 & & & & 358 & .356 & .358 \\
\hline Opportunity to use & .583 & .051 & $.60^{* * *}$ & & & \\
\hline Model 2 & & & & .386 & .381 & .028 \\
\hline Opportunity to use & .348 & .088 & $.36^{* * *}$ & & & \\
\hline Openness to change & .286 & .888 & $.29^{* \star}$ & & & \\
\hline Model 3 & & & & .414 & .407 & .028 \\
\hline Opportunity to use & .230 & .093 & $.24^{*}$ & & & \\
\hline Openness to change & .205 & .090 & $.21^{*}$ & & & \\
\hline Support: peers & .245 & .074 & $.26^{* *}$ & & & \\
\hline Model 4 & & & & .438 & .428 & .023 \\
\hline Opportunity to use & .204 & .092 & $.21^{*}$ & & & \\
\hline Openness to change & .188 & .088 & $.19^{*}$ & & & \\
\hline Support: peers & .082 & .090 & .09 & & & \\
\hline Support: supervisors & .042 & .078 & $.26^{\star *}$ & & & \\
\hline \multicolumn{7}{|l|}{ Model 5} \\
\hline Opportunity to use & .204 & .091 & $.21^{*}$ & .449 & .437 & .011 \\
\hline Openness to change & .168 & .088 & .17 & & & \\
\hline Support peers & .068 & .089 & .07 & & & \\
\hline Support supervisors & .156 & .088 & .16 & & & \\
\hline Sanctions Supervisors & .156 & .073 & $.16^{*}$ & & & \\
\hline Model 6 & & & & .449 & .435 & .000 \\
\hline Opportunity to use & .203 & .092 & $.21^{*}$ & & & \\
\hline Openness to change & .161 & .094 & .17 & & & \\
\hline
\end{tabular}




\begin{tabular}{lcccccc}
\hline \multicolumn{1}{c}{ Predictor } & b & SEb & B & $\mathbf{R}^{\mathbf{2}}$ & Adj. $\mathbf{R}^{\mathbf{2}}$ & $\mathbf{\Delta R}^{\mathbf{2}}$ \\
\hline Support peers & & & & & \\
Support supervisors & .068 & .089 & .07 & & \\
Sanctions supervisor & .146 & .097 & .15 & & \\
Feedback & .152 & .075 & $.15^{\star}$ & & \\
\end{tabular}

Table 5. Results of the multiple hierarchical regression predicting motivation to transfer from Opportunity to Use, Openness to Change, Support-peers, Support-supervisors, Sanctions-supervisors, and Feedback for the work context.

\section{Hypothesis 2:}

In the first step of the regression analysis opportunity to use was entered. For the study context the model was statistically significant $(p<0.001)$ with an $\mathrm{R}^{2}$ of 0.184 indicating that it explained $18 \%$ of the variance in motivation to transfer to study. For the work context the model was also statistically significant $(p<0.001)$. $R^{2}$ was 0.358 which indicates that $36 \%$ of the variance in motivation to transfer to work was explained by this model.

\section{Hypothesis 3:}

In step two of the regression analysis openness to change was added. For the study context the model was statistic significant $(p<0.001)$ and $R^{2}$ showed a minimal increase to 0.186 , indicating that this model also counted for $18 \%$ of variance in motivation to transfer to study. Related to work the model showed statistical significance $(p<0.001)$ with a $\mathrm{R}^{2}$ of 0.386 explaining $39 \%$ of the variance in motivation to transfer to work.

\section{Hypothesis 4:}

In the third step of the regression analysis support by peers (fellow students or colleagues) was entered. For the study context the model showed statistical significance $(p<0.001)$ with an $\mathrm{R}^{2}$ of 0.209 . This indicates that the model explained $21 \%$ of the variance in motivation to transfer to study. For the work context the model was statistically significant $(p<0.001)$. $R^{2}$ was 0.414 which explained $41 \%$ of the variance in motivation to transfer to work.

\section{Hypothesis 5:}

Step four added support by supervisors (lecturers of supervisors) to the regression analysis. Related to the study context the model was statistically significant $(p<0.001)$ with an $\mathrm{R}^{2}$ of 0.219 which explains $22 \%$ of the variance in motivation to transfer to study. For the work context this fourth model also was statistically significant $(p<0.001)$ with $R^{2}$ of 0.438 explaining $44 \%$ of the variance in motivation to transfer to work.

\section{Hypothesis 6:}

In step five sanctions by supervisors (lecturers or supervisors) was added to the regression analysis. In the study context the model showed statistical significance $(p<0.001)$ with a relatively substantial and significant raise of $R^{2}$ to 0.289 . This explains $29 \%$ of the variance in motivation to transfer to study. Related to work the model was again statistically significant $(p<0.001)$ with $\mathrm{R}^{2}$ increasing slightly to .449 , explaining a variance of $45 \%$ in motivation to transfer to work 


\section{Hypothesis 7:}

In the sixth and final step feedback was added to the regression analysis. Related to the study context the model showed statistical significance $(p<0.001)$ with a negligible increase of $R^{2}$ to 0.290 . This means that the final model explained $29 \%$ of the variance in motivation to transfer to study. For the work context the model was statistically significant $(p<0.001)$ and showed no increase, keeping $\mathrm{R}^{2}$ at .449 . Related to work this final model ultimately explained a variance of $45 \%$ in motivation to transfer to work

\section{Discussion}

The overall conclusion of this study is that already before the course has started the learner's motivation to transfer new learning from the course is influenced by expectations about the organizational climate variables used in this research, both in the study and in the work context. This is in line with previous research (Gagné \& Deci, 2005; Gegenfurtner et al., 2009; Machin \& Fogarty, 2004). The results from this study also indicate that in the study context $29 \%$, and in the work context $45 \%$ of variance in motivation to transfer is explained by the variables included in the respective final models. This indicates that it might prove useful to take these variables into account when designing interventions that enhance transfer. In both the study and work context the prospect of having the opportunity to use newly acquired competences from the course and (the fear of) negative reactions by supervisors show to be the most important predictors for the motivation to transfer new learning from the course. One could conclude that already before the intervention it is important to communicate explicitly to the students in what way they might benefit from the application of the acquired competences, also outside their study environment. It might also indicate that delivering the course at the right moment, that is when the students really feel the need for the competences they will acquire, is of vital importance. One might not expect that students, who often are unfamiliar with the advantages of being information literate, already before the course are autonomous or intrinsically motivated to apply new learning from the course. One can only hope that this will change due to for example framing the course accordingly, and to the student's experiences during the intervention. To get more insight into this process we recommend to study the transfer process from a longitudinal perspective, starting before and continuing after an intervention.

This study will contribute to the theoretical development of research on education designed or useful for multiple contexts, and of research on the influence of motivation on the quality of learning and transfer. One limitation of this study is the use of self-report questionnaires. During the course of this research however these will be complemented with interviews with a number of students to get a more detailed account of their choices in the questionnaires. Another limitation is the Open University environment where this study takes place. In general the adult students show a relatively high level of motivation to study and possibly also to transfer. Therefore we recommend to carry out this study also in another environment where learning is directed towards application in study and work, for example a university of applied sciences. Future steps in this research will investigate the influence of learner characteristics and intervention variables on the motivation to transfer learning to multiple contexts, as well as their longitudinal development over time, measured directly after and three months after the course. 


\section{References}

ACRL (2015). Framework for Information Literacy for Higher Education Retrieved 20-052015, 2015, from http://www.ala.org/acrl/standards/ilframework

Ajzen, I. (1991). The Theory of Planned Behavior. Organizational Behavior and Human Decision Processes, 50(2), 179-211. doi: http://dx.doi.org/10.1016/07495978(91)90020-T

Baldwin, T. T., \& Ford, J. K. (1988). Transfer of Tranining: a review and directions for future research. [Article]. Personnel Psychology, 41(1), 63-105.

Baldwin, T. T., Ford, J. K., \& Blume, B. D. (2009). Transfer of Training: 1988 - 2008. In G. Hodgkinson (Ed.), International Review of Industrial and Organizational Psychology (Vol. 24, pp. 41 - 70): John Wiley \& Sons Ltd.

Blume, B. D., Ford, J. K., Baldwin, T. T., \& Huang, J. L. (2010). Transfer of Training: A MetaAnalytic Review. Journal of Management, 36(4), 1065-1105. doi: $10.1177 / 0149206309352880$

Brand-Gruwel, S., Wopereis, I., \& Walraven, A. (2009). A descriptive model of information problem solving while using internet. Computers \& Education, 53(4), 1207-1217. doi: http://dx.doi.org/10.1016/j.compedu.2009.06.004

Burke, L. A., \& Hutchins, H. M. (2007). Training Transfer: An Integrative Literature Review. Human Resource Development Review, 6(3), 263-296. doi: $10.1177 / 1534484307303035$

Cheng, E. W., \& Hampson, I. (2008). Transfer of training: A review and new insights. International Journal of Management Reviews, 10(4), 327-341. doi: 10.1111/j.1468-2370.2007.00230.x

Cheng, E. W., \& Ho, D. C. (2001). A review of transfer of training studies in the past decade. Personnel Review, 30(1), 102-118. doi: doi:10.1108/00483480110380163

Colquitt, J. A., LePine, J. A., \& Noe, R. A. (2000). Toward an integrative theory of training motivation: A meta-analytic path analysis of 20 years of research. Journal of Applied Psychology, 85(5), 678-707. doi: 10.1037/0021-9010.85.5.678

Costello, A. B., \& Osborne, J. W. (2005). Best Practices in Exploratory Factor Analysis: Four Recommendations for Getting the Most From Your Analysis. Practical Assessment Research \& Evaluation, 10(7), 1 - 9.

De Rijdt, C., Stes, A., van der Vleuten, C., \& Dochy, F. (2013). Influencing variables and moderators of transfer of learning to the workplace within the area of staff development in higher education: Research review. Educational Research Review, 8(0), 48-74. doi: http://dx.doi.org/10.1016/j.edurev.2012.05.007 
Facteau, J. D., Dobbins, G. H., Russell, J. E., Ladd, R. T., \& Kudisch, J. D. (1995). The Influence of General Perceptions of the Training Environment on Pretraining Motivation and Perceived Training Transfer. Journal of Management, 21(1), 1-25. doi: http://dx.doi.org/10.1016/0149-2063(95)90031-4

Ford, J. K., Quinones, M. A., Sego, D. J., \& Sorra, J. (1992). Factors affecting the opportunity to perform trained tasks on the job. Personnel Psychology, 45(3), 511-527. doi: 10.1111/j.1744-6570.1992.tb00858.x

Ford, J. K., Yelon, S. L., \& Billington, A. Q. (2011). How much is transferred from training to the job? The $10 \%$ delusion as a catalyst for thinking about transfer. Performance Improvement Quarterly, 24(2), 7-24. doi: 10.1002/piq.20108

Gagné, M., \& Deci, E. L. (2005). Self-determination theory and work motivation. Journal of Organizational Behavior, 26(4), 331-362. doi: 10.1002/job.322

Gegenfurtner, A. (2011). Motivation and transfer in professional training: A meta-analysis of the moderating effects of knowledge type, instruction, and assessment conditions. Educational Research Review, 6(3), 153-168. doi: http://dx.doi.org/10.1016/j.edurev.2011.04.001

Gegenfurtner, A., Veermans, K., Festner, D., \& Gruber, H. (2009). Integrative Literature Review: Motivation to Transfer Training: An Integrative Literature Review. Human Resource Development Review, 8(3), 403-423. doi: 10.1177/1534484309335970

Haskell, E. (2001). Transfer of Learning: Cognition, Instruction, and Reasoning. San Diego, USA: Academic Press.

Holton III, E. F., Bates, R. A., \& Ruona, W. E. (2000). Development of a Generalized Learning Transfer System Inventory. Human Resource Development Quarterly, 11(3), 333-360.

Machin, M. A., \& Fogarty, G. J. (2004). Assessing the antecedents of transfer intentions in a training context. International Journal of Training and Development, 8(3), 222-236. doi: $10.1111 / \mathrm{j} .1360-3736.2004 .00210 . x$

Merriënboer, J. J. v., \& Kirschner, P. A. (2007). Ten Steps to Complex Learning; A systematic approach to four-component instructional design. London: Lawrence Erlbaum Associates, Publishers.

Nijman, D. J. (2004). Supporting transfer of training: Effects of the supervisor (PhD), Universiteit Twente, Enschede. Retrieved from http://doc.utwente.nl/76049/

Noe, R. A. (1986). Trainees' Attributes and Attitudes: Neglected Influences on Training Effectiveness. The Academy of Management Review, 11(4), 736-749. doi: $10.2307 / 258393$ 
Rouiller, J. Z., \& Goldstein, I. L. (1993). The relationship between organizational transfer climate and positive transfer of training. Human Resource Development Quarterly, 4(4), 377-390. doi: 10.1002/hrdq.3920040408

Ruona, E. A., Leimbach, M., Holton III, E., \& Bates, R. A. (2002). The relationship between learner utility reactions and predicted learning transfer among trainees. International Journal of Training and Development, 6(4), 218-228. doi: $10.1111 / 1468-2419.00160$

Russ-Eft, D. (2002). A Typology of Training Design and Work Environment Factors Affecting Workplace Learning and Transfer. Human Resource Development Review, 1(1), 45-65. doi: 10.1177/1534484302011003

Seyler, D. L., Holton III, E. F., Bates, R. A., Burnett, M. F., \& Carvalho, M. A. (1998). Factors Affecting Motivation to Transfer Training. International Journal of Training and Development, 2(1), 16-16. doi: 10.1111/1468-2419.00031

Yamnill, S., \& McLean, G. N. (2001). Theories supporting transfer of training. Human Resource Development Quarterly, 12(2), 195-208. doi: 10.1002/hrdq.

\section{Biographical notes}

Laurent Testers, Subject librarian at NHTV Breda University of Applied Sciences, the Netherlands. Professionally involved in information literacy education. External PhD student at Welten Institute of the Open University of the Netherland. His main interests include transfer of learning, motivation, and information literacy.

Andreas Gegenfurtner, Assistant Professor at the Department of Educational Development and Research, Maastricht University, the Netherlands. His main research interests include motivation and professional learning.

Saskia Brand-Gruwel, Professor in the Learning Sciences. Institute chair of Welten Institute of the Open University of the Netherlands. Her main interests include educational research, e-learning, and information literacy. 